\title{
Ananiasz Zajączkowski - orientalistyka przede wszystkim
}

\author{
Maria Emilia Zajączkowska-Łopatto
}

Związek Karaimów Polskich

Ananiasz Zajączkowski - above all Orientalistics

Summary: In November 1945 Professor Ananiasz Zajączkowski was appointed director of the Oriental Institute of Warsaw University for 5 years. Later, he became its director once more in the years 1957-1961. His primary task was to prepare the groundwork for launching the normal curriculum. In 1948 he started a five-year cycle of study in which he educated several generations of oriental philologists, who conducted research on the Muslim East. In the years 1946-1950 he was head of the Institute of Oriental Studies at the University of Wroclaw.

In 1952 he became a member of the newly formed Polish Academy of Science, where he organized the Committee of Oriental Studies, which he headed till 1965. In 1953, the Department of Oriental Studies of Polish Academy of Science was created and Professor Zajączkowski directed it from its very beginnings until its closure in 1969 . He devoted his entire life to oriental studies. In addition to teaching, the Professor also focused on research and publishing, as well as editorial and organizational work. He was president of the Polish Society of Oriental Studies from 1949 to 1958. He was the editor of the "Oriental Review" between 1948 and 1952, and issued sixteen volumes of the Rocznik Orientalistyczny from 1950 to 1970. In addition, he collaborated in the editing of Jezyk Polski and Poradnik Jezykowy. He was invited to give lectures at the Institute of Eastern Studies in Moscow, at the University of Jerusalem, the Instituto Universitario in Naples, etc. He was the president of the Board of the Polish Team working on the UNESCO "East-West" project. He played 
an active academic and organizational role in several dozen conferences, congresses and convention. He was a member of the Société FinnoOugrienne, Türk Dil Kurumu, Societas Uralo-Altaica, PAU, TNW, Wroclaw Scientific Society. Professor Ananiasz Zajączkowski is the author of 341 publications. To mark the $60^{\text {th }}$ anniversary of his birth the $36^{\text {th }}$ volume of Ural-Altaische Jahrbücher was named in his honour. Dozens of articles have been written about him and his work on Ottoman studies, the Kipchak monuments, the Golden Horde and the historical Turkish literature of Mameluke Egypt.

Keywords: Ananiasz Zajączkowski, Warsaw Univeristy, Institute of Oriental Studies, Department of Turcology, Orientalistics, Turcology, Iranistics, Oriental Committee, Polish Academy of Science, Department of Oriental Studies of the Polish Academy od Science, Polish Oriental Society, EastWest Major Project at UNESCO

Kiedy Profesor Ananiasz Zajączkowski w listopadzie 1945 r. powrócił po dramatycznych przeżyciach wojennych do Warszawy, miał 42 lata, żonę i troje dzieci, nie miał gdzie mieszkać (dom na ul. Brzozowej został zbombardowany i spalony, tak jak i całe Stare Miasto), ale posiadał niezwykle silną pasję tworzenia. Orientalistyka w miarę poznawania, w miarę zagłębiania się w jej tajniki, stała się nieodłączną częścią Jego życia. To nie był po prostu zawód, to było powołanie. Lecz pasja czy powołanie to tylko połowa drogi do sukcesu. Druga połowa to pracowitość. Wszystko, co robił: praca dydaktyczna, badawcza, translatorska, edytorska, działalność organizacyjna, miało służyć tworzeniu i rozwijaniu wschodoznawstwa, jego popularyzacji i uświadamianiu jego znaczenia dla kultury ogólnej.

Jak wielu innych przedwojennych uczonych, nie tylko cenił sobie tytuł profesora, ale także rozumiał obowiązki wynikające z jego posiadania. Czasy były ciężkie i biedne. Warszawa leżała w gruzach. Każdy robił to, co najlepiej potrafił, aby odbudować Stolicę i przywrócić ją do normalnego życia.

Jako jedynemu profesorowi nominowanemu (jeszcze w 1935 r.) powierzono mu stanowisko dyrektora Instytutu Orientalistycznego na Wydziale Humanistycznym Uniwersytetu Warszawskiego. Niezwłocznie podjął pracę nad odbudowaniem całkowicie zniszczonego Instytutu i stworzeniem - po raz drugi - swojej Katedry. Przez dwa lata dojeżdżał EKD z Podkowy Leśnej do Warszawy. Dopiero we wrześniu 1947 r. zamieszkał wraz z rodziną w 2-pokojowym mieszkaniu w odbudowanym domu Spółdzielni Profesorów UW przy 
ulicy Sewerynów 6. Nie dysponował niczym, nie było ani personelu pomocniczego, ani lokalu, ani księgozbioru, ani studentów ${ }^{1}$. Ze słuchaczy Seminarium Turkologicznego Hanka Stefanowska, bardzo zdolna studentka, zginęła w czasie Powstania Warszawskiego w 1944 r. w kanałach przy wyjściu z Mokotowa, na Woli poległ studiujący nawet podczas okupacji Piekarski, Józef Sulimowicz pozostał w wojsku, Kamila Ibrahimow wyjechała do Anglii, inni jeszcze się nie odnaleźli. Dzień po dniu Profesor zdobywał sprzęty: tablicę, biurko, krzesła, wieszak. Zdobył też pokój na I piętrze uniwersyteckiego gmachu pomuzealnego. Jeździł po kraju, aby odszukać księgozbiór zabrany z Wrocławia, i częściowo przywiózł go do Warszawy². Uruchomił Katedrę i już w 1946 r. zaczął pracę dydaktyczną. Pierwsze magisteria uzyskali przedwojenni studenci: Stanisława Płaskowicka i Jan Reychman. Zostali zatrudnieni w Katedrze na etatach asystenckich ${ }^{3}$.

Regularne wykłady rozpoczęły się w roku 1948. Profesor Zajączkowski wykładał wstęp do nauki o kulturze Islamu, dyplomatykę Złotej Ordy, gramatykę opisową języka tureckiego, czytał ze studentami epos nowoperski Firdausiego oraz Gulistan Saadiego, a także prowadził seminarium turkologiczne i lektorat języka arabskiego ${ }^{4}$. Nowy ramowy projekt pięcioletnich studiów magisterskich powstał w $1951 \mathrm{r}$. i obejmował obowiązkowo przedmioty pozaorientalistyczne (np. językoznawstwo ogólne, dwa lektoraty języków zachodnich i języka rosyjskiego) ${ }^{5}$. Swoje studia turkologiczne tradycyjnie „obejmujące filologię całego Bliskiego Wschodu, tzw. elsene-i selase, znajomość trzech języków dominujących na tym obszarze" - wspominał prof. dr hab. Tadeusz Majda, zastanawiając się nad ich dalszym rozwojem ${ }^{6}$. Ten rozwój stale trwa i obecnie po powstaniu Wydziału Orientalistycznego zaistniały optymalne warunki do tworzenia nowych kierunków i kształcenia nowych wychowanków.

1 E. Tryjarski, Restoration of Oriental Studies in Poland after the World War II as Reflected in Five Letters by Tadeusz Kowalski, „Studia Turcologica Cracoviensia” 1998, nr 5, s. 267-285.

2 T. Majda (red.), Urzeczeni Orientem. Listy Profesora Ananiasza Zajaczkowskiego do Profesora Tadeusza Kowalskiego, Warszawa 2013, s. 208, 210.

3 Uniwersytet Warszawski. Skład Uniwersytetu i Spis Wykładów na rok akademicki 1948-1949. Warszawa 1948, s. 35.

4 Ibidem, s. 66-67, 69.

5 S. Kałużyński, Uniwersyteckie studia orientalistyczne $w$ Polsce, „Przegląd Orientalistyczny" 1994, nr 1-2 (169-170), s. 6-7.

6 T. Majda, Studia turkologiczne w Polsce i zagranica, „Przegląd Orientalistyczny” 1994, nr 1-2 (169-170), s. 25-27. 
Jeszcze w końcu lat 50. nie było ani skryptów, ani podręczników. Należało robić notatki na wykładach i ćwiczeniach, by uzupełniać je potem literaturą przedmiotu, w kilku językach obcych najczęściej. Brakowało słowników. Pracowali już lektorzy (native speakerzy) języków perskiego i arabskiego, ale wciąż nie przyjeżdżał lektor języka tureckiego. Dopiero w 1961 r. lektorat ten objęła Münevver Borzęcka-Andaç. Zawdzięczaliśmy jej wielce interesujące opowieści o Stambule, o życiu zwyczajnych ludzi i intelektualistów, o teatrze i filmie, o malarzach i przede wszystkim o współczesnych pisarzach i poetach tureckich. Z czasem podstawowe wykłady oraz ćwiczenia z gramatyki poszczególnych języków arabskiego, tureckiego i perskiego prowadzili asystenci czy adiunkci, a Profesor co czwartek miał seminarium turkologiczne oraz wykład monograficzny o leksykografii tureckiej lub o gramatyce porównawczej języków tureckich, albo też o literaturze tureckiej itd. O studiach, wykładach i egzaminach u Profesora napisała wzruszające wspomnienie mgr Zofia Dubińska ${ }^{7}$. Przytoczyła m.in. zdanie jednej z koleżanek, która twierdziła, „że my, którzy w tym pierwszym okresie składaliśmy wszystkie egzaminy u Profesora, stanowimy arystokrację orientalistyki naszej, bowiem poznaliśmy niepowtarzalną filologiczno-humanistyczną szkołę Profesora"».

Przedstawiciele tej arystokracji otrzymywali po ukończeniu studiów etaty asystenckie w katedrze, bronili prac doktorskich (J. Bielawski, A. Dubiński, S. Kałużyński, T. Majda, B. Składanek, E. Szymański, E. Tryjarski, M. Żołna-Składankowa), robili habilitacje i stawali się twórcami odrębnych katedr. Uczniowie Profesora mogli wybierać nie tylko kierunki badań, ale i tematy, które ich interesowały. Wychował kilka pokoleń turkologów, iranistów i arabistów. I tak arabiści z czasem do Katedry Turkologii dodali Zakład Arabistyki, aby potem stworzyć Katedrę Arabistyki i Islamistyki z prof. dr hab. Józefem Bielawskim na czele, a iraniści, profesorowie Maria i Bogdan Składankowie, na bazie Zakładu Turkologii i Iranistyki stworzyli Katedrę Iranistyki. Katedrę zaś Filologii Ludów Azji Środkowej, której w latach 1955-1963 profesor Zajączkowski był kuratorem, przejął i rozwinął prof. dr hab. Stanisław Kałużyński.

Pierwszy Słownik turecko-polski i polsko-turecki wydali w „Wiedzy Powszechnej” w Warszawie w 1983 r. (wyd. II 2008), byli studenci Profesora, mgr Lucyna Antonowicz-Bauer i dr Aleksander Dubiński. Mgr Alina Barbara Mrozowska pracowała w Zbiorach Specjalnych Biblioteki Uniwersyteckiej, zajmowała się

\footnotetext{
7 Z. Dubińska, Garść wspomnień o Mistrzu, [w:] Kipčiaku tiurku Orientas Lietuvoje. Istorija ir tyrimu perspektyva, red. T. Bairašauskaite, H. Kobeckaitè, Vilnius 1994, s. 96-101.

8 Tamże, s. 100.
} 
rękopisami wschodnimi. Inni adepci turkologii i iranistyki pracowali w wydawnictwach PWN, PIW i innych.

W latach 1948-1950 Profesor Zajączkowski kierował działem Bliskiego Wschodu w trzyletnim Studium Języków i Zagadnień Wschodnich przy Instytucie Spraw Międzynarodowych. Niektórzy słuchacze tego Studium przenieśli się do Instytutu Orientalistycznego UW 9 .

Jednocześnie przez prawie 5 lat kierował Instytutem Orientalistyki na Wydziale Humanistycznym Uniwersytetu we Wrocławiu, prowadził wykłady i ćwiczenia ${ }^{10}$. To tutaj zaczynał prof. dr hab. Stanisław Kałużyński, późniejszy prorektor UW, zaś starsza asystentka, a potem adiunkt w Katedrze Turkologii, dr Renata Stark-Kohnowa po wyjeździe z Polski wykładała na Uniwersytecie Hebrajskim w Jerozolimie. Profesor Zajączkowski uczestniczył w założeniu w 1946 r. Wrocławskiego Towarzystwa Naukowego. We Wrocławiu wydał dwa powojenne numery „Myśli Karaimskiej”, a także w serii A Prac Towarzystwa trzy swoje prace: Glosy tureckie w zabytkach staropolskich. I Katechizacja turecka J. Herbiniusa z r. $1675 \mathrm{w}$ roku 1948, Zwiazki jezykowe połowiecko-słowiańskie w 1949 oraz Studia orientalistyczne z dziejów słownictwa polskiego w 1953. W 1965 r. własnoręcznie wpisał swój życiorys do „Złotej Księgi Uniwersytetu Wrocławskiego” przechowywanej w Archiwum Uniwersyteckim, a jego nazwisko widnieje w Muzeum Uniwersyteckim na Wieży Matematycznej, na tablicy upamiętniającej pierwszych powojennych profesorów, którzy wykładali we Wrocławiu.

Oprócz działalności dydaktycznej profesor Zajączkowski prowadził aktywną działalność organizacyjną. Energicznie włączył się w prace Polskiego Towarzystwa Orientalistycznego i na zwołanym w 1947 r., pierwszym po przerwie wojennej, VIII Zjeździe Orientalistów Polskich w Krakowie został wybrany wiceprezesem, a na IX Zjeździe prezesem Towarzystwa i pozostał na tym stanowisku do roku 1958. Od 1948 r. przez 5 lat był redaktorem naczelnym pierwszego w Polsce popularnonaukowego pisma wschodoznawczego „Przegląd Orientalistyczny”"1 powstałego z przekształcenia „Myśli Karaimskiej”, a następnie przez kolejnych 5 lat stał na czele jego Rady Redakcyjnej. Miał widać szczęśliwą rękę,

\footnotetext{
9 A. B. Mrozowska, Wspomnienia o Profesorze Ananiaszu Zajaczkowskim, [w:] Kipčiaku tiurku Orientas Lietuvoje..., s. 88-95.

10 M. Abkowicz, Wrocławskie epizody karaimskie, [w:] Wybitni wrocławianie. Osobowości whistorii miasta, red. I. Lipman, J. Nowosielska-Sobel, G. Strauchold, Wrocław 2010, s. 157-167.

11 L. Cyrzyk, Rola „Przegladu Orientalistycznego” w upowszechnianiu wiedzyo Wschodzie, „Przegląd Orientalistyczny” 1976, nr 4 (100), s. 336.
} 
bo „Przegląd Orientalistyczny”, jak wiemy ukazuje się do dziś, redagowany przez coraz to młodsze pokolenia adeptów orientalistyki.

Od roku 1950 współredagował „Rocznik Orientalistyczny”, a od 1953 do zgonu pełnił obowiązki jego redaktora naczelnego, wydając 16 tomów (XIXXXXIV). Był też współredaktorem serii „Prace orientalistyczne”, w której wydał 21 prac, w tym trzy własne.

W 1952 r. powstaje Polska Akademia Nauk. Profesor Zajączkowski zostaje jej członkiem i od razu przygotowuje plany dalszego rozwoju orientalistyki, wykorzystując nowe możliwości związane z tą instytucją, a przede wszystkim z powołanym w niej Komitetem Orientalistycznym, przekształconym następnie w Komitet Nauk Orientalistycznych PAN, a w 1960 r. w Sekcję Orientalistyczną Komitetu Nauk Filologicznych, by w 1962 r. restytuować dawną nazwę. Profesor Zajączkowski stanął na czele prezydium Komitetu i kierował jego pracami do momentu zawieszenia działalności w 1966 r. Na posiedzeniach Komitetu wygłosił w tym czasie 15 referatów ${ }^{12}$.

W 1953 r. tworzy swoje „najmłodsze dziecko”: Zakład Orientalistyki PAN. Wiąże z działalnością badawczą Zakładu ogromne nadzieje. Organizuje pracownię rękopisów orientalnych, leksykograficzną i historyczną. Później struktura Zakładu ulega zmianie. Powstaje dział Bliskiego i Środkowego Wschodu oraz Dalekiego Wschodu, a także Pracownia Dokumentacji i Informacji. Prace wykonane w Zakładzie nad rękopisami orientalnymi w zbiorach polskich, badania nad językiem tureckim Ormian polskich, wreszcie wydany we współpracy z Akademiami Nauk Rosyjską i Litewską, już po zamknięciu Zakładu, bo w 1974 r., Słownik karaimsko-rosyjsko-polski $i^{13}$, stanowią trwały wkład w rozwój polskiej orientalistyki. Najbardziej ambitnym programem Zakładu było stworzenie słownika kipczackiego. Nad tym projektem pracowali Halina Natorf i Tadeusz Majda. Prawdopodobnie z tego względu „Hetman”, jak zwano ówczesnego wszechwładnego sekretarza naukowego PAN, nadał Ananiaszowi Zajączkowskiemu przydomek „Wielki Kipczak”. Adekwatność przydomka potwierdzały wydawane sukcesywnie zabytki piśmiennictwa kipczackiego, takie jak np. Słownik arabsko-kipczacki z okresu Państwa Mameluckiego, Bulġat al-muštāq fī luġat

12 M. Kozłowska (oprac.), Komitet Nauk Orientalistycznych Polskiej Akademii Nauk. Spis referatów wygłoszonych na posiedzeniach naukowych 1952-2012, Warszawa 2012, s. 7, 9-14, 19-21. O roli Profesora A. Zajączkowskiego w pracach Komitetu zob. też S. Kałużyński, Działalność organizacyjna prof. A. Zajączkowskiego, „Przegląd Orientalistyczny” 1971, nr 3 (79), s. 278.

13 N. A. Baskakov, A. Zajončkovskij, S. M. Šapšal (red.), Karaimsko-russko-pol'skij slovar', Moskwa 1974. 
at-Turk wa-l- Qifžāq (Warszawa 1958) czy Le traité arabe Mukaddima d'Abou-l-Lait as-Samarkandī en version mamelouk-kiptchak (Warszawa 1962). O swojej pracy nad zabytkami kipczackimi rozpoczętej jeszcze w 1930 r. w Paryżu, opowiedział w króciutkim wykładzie o Deszt-i Kipczak na Sesji Jubileuszowej XXX-lecia Instytutu Orientalistycznego ${ }^{14}$. Wtedy jeszcze nie wiedział, że Zakład Orientalistyki PAN zostanie ostatecznie zamknięty w 1969 r., a projekt wydania słownika „Thesaurus Linguae Kipčacorum” pozostanie jedynie marzeniem ${ }^{15}$.

W ostatnich latach życia pracował gorączkowo. Śpieszył się, bał się, że nie zdąży skończyć zaczętej pracy. „Od kilku dni «chwycił» mnie nowy temat, siedzę dosłownie nie podnosząc głowy przy maszynie i od razu walę na papier - i to w obcym języku - wstęp do nowo zamierzonej edycji drugiego «Traktatu o sztuce wojennej», tym razem irańskiego (300 str.!). Bardzo to mnie męczy, zwłaszcza pisanie na maszynie, choć już inaczej nie piszę prac"16. Le traité iranien de l'art militaire Ādāb al-ḥarb wa-šs-šăga à du XIII siècle. Introduction et édition en facsimilé(MS. British Museum, Londres) został wydany w serii Prace Orientalistyczne nr $21 \mathrm{w} 1969$ r. „Moje wydanie traktatu perskiego o sztuce wojennej przyjęto zagranicą nadspodziewanie entuzjastycznie (...) Smętnie się uśmiecham, bo tylko ja wiem, ile trudu kosztuje mnie za każdym razem rozpoczęcie nowego tematu, ale cieszę się, że temat został wybrany celnie i dobrze. A wciąż nowe tematy kuszą mnie bardzo..." - napisał 5 stycznia 1970 r. z Warszawy w jednym z ostatnich listów do bratanicy, Marianny Zajączkowskiej-Abrahamowicz.

Obok pracy dydaktycznej i badawczej ważną częścią działalności profesora Zajączkowskiego było organizowanie i czynne uczestniczenie w obchodach rocznic orientalnych, takich jak np. 1000-lecie urodzin Awicenny. Przy tej okazji napisał kilka artykułów oraz szkic Awicenna i jego epoka, w którym umieścił także tłumaczenia czterowierszy ${ }^{17}$. Po raz pierwszy pojechał do Iranu na uroczystości związane z tą rocznicą. Miał okazję w Szyrazie pokłonić się Mauzoleum Szamseddina Hafeza, zapoznać się z najwybitniejszymi iranistami

14 A. Zajączkowski, Studia nad zabytkami kipczackimi, [w:] Sesja Jubileuszowa XXX-lecia Instytutu Orientalistycznego Uniwersytetu Warszawskiego (21-22.I.1964). Komunikaty Naukowe, Warszawa 1964, s. 70-75.

15 A. Zajączkowski, O potrzebie edycji i planie wydawniczym „Słownika Kipczackiego” (Thesaurus Linguae Kipčacorum), [w:] Sprawozdania z posiedzeń Komisji Naukowych PAU, Kraków 1950, 50, 10, s. 591-594.

16 List do bratanicy, Marianny Zajączkowskiej-Abrahamowicz, pisany w Warszawie 24 maja 1968 r. Archiwum rodzinne.

17 A. Zajączkowski, Awicenna i jego epoka, [w:] Awicenna Abu Ali Ibn Sina, Praca zbiorowa pod red. Ananiasza Zajączkowskiego, Warszawa 1953, s. 7-73. 
owych czasów i nawiązać współpracę z badaczami z Teheranu. Rozpoczęła się wymiana wydawnictw, pojawiła się nawet szansa dla młodych adeptów iranistyki na otrzymanie stypendium naukowego do Iranu.

Następnym bardzo ważkim wydarzeniem były obchody Roku Mickiewiczowskiego w stulecie śmierci Wieszcza. A. Zajączkowski wydał w Państwowym Instytucie Wydawniczym książkę Orient jako źródło inspiracji w literaturze romantycznej doby mickiewiczowskiej (Warszawa 1955), opublikował też artykuł $Z$ dziejów orientalizmu polskiego doby mickiewiczowskiej"18. A po latach wygłosił w Rzymie referat pod tytułem Mickiewicz et l'Orient ${ }^{19}$.

$\mathrm{Z}$ racji piastowanych stanowisk brał też udział chociażby w organizowaniu rozmaitych ekspozycji, jak „Wystawa orientalna” w Muzeum Narodowym w Warszawie w 1950 r., „Pismo i książka orientalne” w 1958 r. czy „Najstarsze polskie druki orientalistyczne” w Bibliotece Uniwersyteckiej w Warszawie w $1962 \mathrm{r}$.

W 1957 r. został wybrany przewodniczącym prezydium polskiej grupy roboczej do spraw realizacji projektu UNESCO „Wschód-Zachód”. Bardzo się angażował w prace tej grupy, gdyż głęboko wierzył w ten projekt. Przybliżanie problemów Wschodu polskiemu odbiorcy, popularyzowanie wiedzy o Oriencie, nieodwracanie oczu od płynącego stamtąd Światła to były przecież idee, którym poświęcił całe swoje pracowite życie. Zawsze uważał, że „Wschód jest nierozerwalnie związany z Zachodem, i tylko dzieje obydwu tych wielkich obszarów kulturalnych składają się na dzieje całej ludzkości." ${ }^{\text {20 }}$

Profesor Ananiasz Zajączkowski za niezwykle ważną zawsze uważał współpracę międzynarodową. Po wojnie, już w 1948 r. pojechał do Paryża na XXI Międzynarodowy Kongres Orientalistów, a potem w 1954 r. na XXIII Kongres do Cambridge, w 1957 r. na XXIV do Monachium i w 1960 r. na XXV do Moskwy. Wziął udział w pięciu Tureckich Kongresach Językowych oraz w dwóch, w latach 1956 i 1961, Tureckich Kongresach Historycznych. W latach 1959-1968 uczestniczył w ośmiu sesjach Stałej Międzynarodowej Konferencji Ałtaistycznej PIAC, w Międzynarodowym Kongresie Sztuki Tureckiej w Wenecji w 1963 r., w Międzynarodowym Kongresie Studiów Bałkanistycznych

18 A. Zajączkowski, Z dziejów orientalizmu polskiego doby mickiewiczowskiej, [w:] Szkice $z$ dziejów polskiej orientalistyki, Warszawa 1957, s. 95-156.

19 Opublikowany w Conferenza tenuta nella seduta ordinaria del 9 dicembre 1967. Problemi attuali di scienza e di cultura, Accademia dei Lincei, Roma 1968, s. 1-13.

20 A. Zajączkowski, O należne miejsce dla kultur Orientu (z okazji zbliżenia kulturalnego z krajami Wschodu), „Nowa Kultura” nr 43 (448), Warszawa 26 X 1958, s. 1, 8. 
i Europy Wschodniej w 1966 r., w Światowym Kongresie Iranistycznym w 1966 r. Do Turcji pierwszy raz po wojnie pojechał na uroczystości mickiewiczowskie w grudniu 1955 r. ${ }^{21}$ To było dla niego wielkie przeżycie. Po siedemnastu latach, po koszmarach wojny miał możność spotkać kolegów i przyjaciól, nawiązać na nowo kontakty i zainicjować wymianę publikacji. Ta i każda następna podróż była dla niego swojego rodzaju świętem i radością. Uwielbiał Stambuł i jego okolice. Podziwiał widoki na Morze Marmara z balkonu ulubionego „Park Oteli”, z Kız Kulesi i Topkapı Burnu, panoramę Złotego Rogu.

Pomimo rozmaitych niedomagań w Stambule czuł się zawsze dobrze. Jadał wyłącznie dania tureckie w bardzo skromnych lokalach obok Uniwersytetu, smażone rybki pod Mostem Galata, czasem w letnie wieczory siadywał z kolegami profesorami w lokantach nad Bosforem, słuchając muzyki i podziwiając konijskie tańce z drewnianymi łyżkami. Bardzo też lubił przedstawienia teatru Karagöz. Latem 1962 r. obejrzeliśmy niezapomniane przedstawienie „Hamleta” w Rumeli Hisar. Lubił spacerować po starym Stambule, rozmawiać ze sprzedawcami na Mısır Çarşısı, siadać na fotelu u pucybutów i rozmawiać z nimi, płynąć stateczkiem do znajomych na Wyspy Książęce, na Büyük Ada czy Heybeli, albo po Bosforze. Wzruszające chwile przeżywał w kienesie karaimskiej w Hasköy.

Nieczęste były w owych czasach wizyty w Polsce tureckich turkologów czy artystów. Do nielicznych takich wydarzeń należały występy pianistki Ayşegül Sarıca, świetnej odtwórczyni sonat Beethovena i utworów Chopina, albo znakomitej divy operowej rodem z Polonezköy, Leyli Gencer, która śpiewała partię Violetty w „Traviacie” Verdiego w Operze Roma przy ul. Nowogrodzkiej. To były radosne chwile rozświetlające szarą codzienność. W ogóle przedstawienia teatralne, koncerty czy muzyka na motywach orientalnych zawsze bardzo interesowały Profesora. Słuchał często poematu symfonicznego "Szecherezada” Rimskiego-Korsakowa, opery „Kniaź Igor” Borodina, tańców perskich z opery „Chowańszczyzna” Mussorgskiego itp. Będąc w Moskwie, oczywiście podziwiał balety „Fontanna Bachczysaraju” czy „Giselle”. Swoimi nastrojowymi balladami urzekał go Bułat Okudżawa. W Baku, w Instytucie Literatury im. Nizamiego omawiał ulubiony wątek o szachu Chosrowie i pięknej księżniczce Szirin, porównując go do europejskiej legendy o Tristanie i Izoldzie. Rozmyślając o losach

21 A. Zajączkowski, Na uroczystościach mickiewiczowskich $w$ Turcji, „Przegląd Orientalistyczny” 1956, nr 2 (18), s. 131-139; Z. Żygulski jun., Światła Stambułu, „Życie Literackie” nr 12, Kraków, 18 marca 1956 r. (Przedruk w: tegoż, Światła Stambułu, Warszawa 1999, s. 11-21). 
Chazarów, przechadzał się nad Morzem Kaspijskim, które dla niego zawsze było Chazarskim. Miał też możność być na koncertach legendarnego Aleksandra Wertyńskiego i młodego Muslima Magomajewa. W Warszawie słuchał romansów cygańskich w wykonaniu Michaja Burano i oczywiście zachwycał się śpiewem Czesława Niemena. Zadziwił słuchaczy swojego Seminarium, opowiadając po powrocie z Manchesteru, gdzie otrzymał doktorat honoris causa, o Beatlesach i nowej modzie młodzieżowej. Często słuchał Radia Luxembourg, lubił Ellę Fitzgerald i Louisa Armstronga. Chodziliśmy na koncerty Lucienne Boyer, Yvesa Montanda, Juliette Greco, Marlene Dietrich.

Kilkakrotnie przebywał w Tbilisi: jesienią 1959 r. wraz z prof. dr hab. Janem Braunem jako członek delegacji z okazji Dekady Kultury Polskiej w Gruzji, a w 1968 r. na jubileuszu Uniwersytetu im. Dżawachiszwili, którego był doctorem honoris causa. Za każdym razem ze wzruszeniem składał kwiaty w Panteonie Mtacminda na grobie Aleksandra Gribojedowa, którego dramat „Mądremu biada” znał na pamięć w oryginale jeszcze z czasów działalności teatralnej na Krymie, gdy w młodzieżowym teatrze grał Czackiego.

Nigdy nie stracił zainteresowania teatrem. To była jego ulubiona rozrywka. Oglądał niemal wszystkie przedstawienia, zarówno klasyczne dramaty i komedie, jak i nowe, zwłaszcza historyczne sztuki współczesnych autorów. Nie omijał także tych o tematyce współczesnej. Takie spektakle jak „Opera za trzy grosze”, „Kaukaskie kredowe koło”, „Dobry człowiek z Seczuanu” Brechta czy "Czekając na Godota” Becketta w Teatrze Współczesnym bardzo go poruszały. Do kina chodził tylko na filmy wybitne, jak „Popiół i diament” i „Kanał” Wajdy, „La dolce vita” i „8 i 1²” Felliniego, „Zaćmienie” Antonioniego czy filmy francuskiej nouvelle vague. W karty grywał jedynie w kinga w czasie pobytów w Nieborowie.

Ulubionym zajęciem była codzienna praca, gdy zasiadał przy biurku, by odczytywać rękopisy, przygotowywać publikacje do druku, robić korekty. Każdy nowy temat bardzo go absorbował. Starał się pracować jak najlepiej, zdawał sobie jednak sprawę, że nie sposób uniknąć błędów. Powtarzał często, że tylko ten, kto nie pracuje, ich nie popełnia. Śpieszył się. Chciał zgłębić temat, aby pójść dalej, do nowych wyzwań. Do niektórych tematów powracał, do innych nie zdążył. I tak w 1947 r. dzięki zasiłkowi Prezydium Rady Ministrów i Wydziału Nauki Ministerstwa Oświaty wydał nakładem Polskiej Akademii Umiejętności w Krakowie pracę Ze studiów nad zagadnieniem chazarskim. Études sur le problème des Khazars (avec resumé français) w serii Prace Komisji Orientalistycznej nr 36. 
Powracał do tematu chazarskiego w późniejszych publikacjach ${ }^{22}$. Cytowany był przez wielu badaczy i pisarzy m.in. Arthura Koestlera, autora ksiażki La treizième tribu. L'Empire khazar et son héritage, wydanej w 1976.

Bibliografia prac Profesora obejmuje 341 pozycji. Życiorysy badacza znajdują się w encyklopediach, nie tylko krajowych. Tak w kraju, jak i zagranicą ukazało się o Nim i jego pracach kilkadziesiąt artykułów. W czerwcu 2014 r. Aygün Ismayilova obroniła pracę magisterską pt. „Dorobek naukowy Ananiasza Zajączkowskiego - wkład w polską i światową orientalistykę", napisaną pod kierunkiem dra hab. Öztürka Emiroğlu w Zakładzie Turkologii i Ludów Azji Środkowej Wydziału Orientalistycznego UW. Prof. dr hab. Józef Bielawski napisał: „Prace tego wybitnego Uczonego, zarówno dotyczące turkologii, jak i iranistyki czy arabistyki, cechuje zawsze wysoki poziom naukowy. Mogą być wzorem dla młodszych pracowników naukowych, zajmujących się muzułmańskim Wschodem, językiem, literaturą czy kulturą w ogóle"23.

Zdaniem profesora Macieja Popki: „W powojennej działalności naukowej wśród pracowników Instytutu Ananiasz Zajączkowski wyróżniał się zdecydowanie liczbą i jakością publikacji i dzięki nim ów uczony osiągnął wybitną pozycję w nauce światowej"24.

Był bardzo punktualny, jeśli miał wyznaczony termin oddania maszynopisu do wydawnictwa, to starał się zrobić to parę dni wcześniej. W miarę upływu lat, dzięki swojej erudycji i nawiązanym jeszcze przed wojną kontaktom był regularnie zapraszany na rozmaite konferencje międzynarodowe, a także na gościnne wykłady w Instytucie Wschodoznawstwa AN w Moskwie, w uniwersytecie w Jerozolimie, w Instituto Universitario Orientale w Neapolu, w uniwersytetach w Moguncji, Stambule, Ankarze i innych. Stosunki z kolegami turkologami rozszerzyły się prawie na wszystkie kraje Europy i republiki Związku Radzieckiego. Utrzymywał ożywioną korespondencję z uczonymi turkologami, swoimi rówieśnikami i młodymi, którzy zwracali się o porady, przysyłali swoje prace do recenzji. W listopadzie 1972 r. byłam zaproszona do Aszchabadu na Międzynarodowy Kongres pod patronatem UNESCO na temat Rozwoju Azji

22 Por. A. Zajączkowski, Khazarian Culture and its Inheritors, „Acta Orientalia Academiae Scientiarum Hungaricae” 1961, t. XII. Fasc. 1-3, s. 299-307.

23 J. Bielawski, Prace iranistyczne i arabistyczne prof. Ananiasza Zajaczkowskiego, „Przegląd Orientalistyczny" 1971, nr 3 (79), s. 282.

24 M. Popko. Z dziejów Instytutu Orientalistycznego UW, [w:] 75 lat Instytutu Orientalistycznego Uniwersytetu Warszawskiego, red. M. Popko, Warszawa 2007, s. 15. 
Środkowej. Jeszcze zanim wygłosiłam swój komunikat ${ }^{25}$, podeszła do mnie ze łzami w oczach pani profesor Irène Mélikoff, opowiadając mi o swojej przyjaźni z moim Ojcem. Po dwudziestu latach nie mogąc przyjechać do Wilna na sesję Mu poświęconą, przysłała tekst ${ }^{26}$.

Takich nieoczekiwanych spotkań było sporo. Przed wielu laty, we Florencji miałam honor gościć akademika Władimira Toporowa, znakomitego językoznawcę semiotyka, który ze wzruszeniem opowiadał o wizycie w Warszawie, kiedy był jeszcze zupełnie młodym naukowcem, a profesor Zajączkowski, już akademik, przyjmował go i zabawiał konwersacją, którą zapamiętał na całe życie. Rosyjscy turkolodzy wspominali go jako „nieizczerpajemogo sobiesiednika”. W Gabinecie Turkologicznym Instytutu Wschodoznawstwa w Moskwie wisiała Jego fotografia, a listy zostały przekazane do Archiwum Rosyjskiej Akademii Nauk. W Warszawie w Archiwum PAN czekają na swoich czytelników papiery profesora Zajączkowskiego i listy otrzymywane od wielu orientalistów zagranicznych.

Profesor marzył, że gdy przejdzie na emeryturę i będzie miał czas dla siebie, napisze wspomnienia na podstawie osobistych notatek i „kroniczek” zapisanych w listach do żony i członków rodziny. Niestety, nie doczekał tego. Nie czuł się dobrze, mimo to pojechał na konferencję do Rzymu, miał jeszcze spotkać w Neapolu profesora Alessio Bombacci, Irène Mélikoff oraz innych przyjaciół i kolegów turkologów. Do Neapolu nie dojechał. Dostał ataku serca na dworcu Termini w Rzymie w piękny słoneczny dzień 6 kwietnia 1970 r. Zmarł, nie dożywszy 67 urodzin. Tę tragiczną wiadomość podała jako pierwsza największa europejska agencja prasowa Reuters, potem francuska AFP, amerykańska AP itd.

Zbyt wiele pracował nie oszczędzając sił, zbyt wiele przecierpiał, zbyt wiele przeżył rozczarowań, zwłaszcza w ostatnich kilku latach życia. Powtarzał często, że tylko ukochana wnuczka Ania jest jego radością. I nawet Komandoria Orderu Odrodzenia Polski, otrzymana w 1969 r. przy okazji 25-lecia Polskiej Akademii Nauk, wedle jego odczucia „przyszła za późno”. O pogrzebie na Cmentarzu Karaimskim w Warszawie opowiedział profesor Stanisław Lorentz, który żegnał Go w imieniu własnym i Polskiej Akademii Nauk ${ }^{27}$.

25 M. Zajączkowska-Hensel, Tracing the History of Central Asian, Mongolian and Iranian Studies in Poland, [w:] Central Asia in Modern Times, wyd. B. G. Gafurov, Moskva 1975, s. 166-176.

26 I. Melikova, Vospominanija tiurkologa o A. Zajončkovskom, [w:] Kipčiaku tiurkų Orientas Lietuvoje, s. 76-81.

27 R. Jarocki, Rozmowy z Lorentzem, Warszawa 1981, s. 85-86. 
Profesor A. Zajączkowski za swój obowiązek uważał dbanie o należyte miejsce orientalistyki wśród nauk humanistycznych. Na posiedzenia Rady Wydziału czy też posiedzenia Senatu, kiedy wybrano go jako reprezentanta Wydziału Neofilologii, przyjeżdżał nawet z pobytu w sanatorium. Współpracował z polonistami, językoznawcami, historykami, slawistami, rusycystami, historykami sztuki, historykami filozofii, prawnikami. Wskazywał na konieczność współpracy historyków z turkologami umiejącymi czytać dokumenty osmańskie czy perskie i arabskie.

W trudnych powojennych czasach, nie będąc członkiem żadnej partii, kierując się tylko rozumem i dobrą wolą, robił wszystko, co było w jego mocy, aby orientalistyka pomimo trudności personalnych, nie rzadko braków łączności z krajami, których język, historię i kulturę studiowano w Instytucie, rozwijała się jak najlepiej.

Wielu pamięta do tej pory charakterystyczną sylwetkę Profesora i nadal na hasło: Karaim, pada, przynajmniej w Warszawie, odzew: Ananiasz Zajączkowski. Cytuje go Stefan Bratkowski w książce Skąd przychodzimy (Warszawa 1993, s. 118), wspomina profesor Władysław Bartoszewski w Pod prad (Warszawa 2011, s. 57) $\mathrm{i}$ inni. Wojciech Wendland, autor wydanej w Krakowie w roku 2013 cennej pracy Trzy czoła Proroków z matki obcej. Myśl historyczna Tatarów polskich $w$ II Rzeczypospolitej, wielokrotnie cytuje listy A. Zajączkowskiego przechowywane w Archiwum Nauki PAN i PAU oraz Archiwum UW.

Wzruszające słowa otrzymałam z Wilna od przedstawiciela Stowarzyszenia Kulturalnego Karaimów Litewskich w Radzie Mniejszości Narodowych Litwy, inż. Romualda Szpakowskiego i jego małżonki, Anny, którzy nie mogąc przyjechać do Warszawy na konferencję „Karaimi turkolodzy” w listopadzie 2013 r., napisali: „Składamy najserdeczniejsze życzenia Rodzinie w dniu 110 rocznicy Urodzin twórcy turkologii warszawskiej Profesora Ananiasza Zajączkowskiego. Jego praca w dziedzinie turkologii to fundament dla następnych pokoleń młodych naukowców-turkologów, dla uzyskania nowych osiągnięć w tej dziedzinie.”

Każda rocznica jest wyśmienitą okazją do podsumowania czy oceny osiągnięć, a także zaprezentowania nowych publikacji, do przedstawienia materiałów archiwalnych będących jednym z podstawowych źródeł do poznania zarówno życia, jak i dzieła dokonanego przez Uczonego. W połowie $2013 \mathrm{r}$. z okazji 80-lecia Instytutu Orientalistycznego UW ukazała się książka Urzeczeni Orientem. Listy Profesora Ananiasza Zajaczkowskiego do Profesora Tadeusza Kowalskiego pod redakcją prof. Tadeusza Majdy, a Związek Karaimów Polskich wydał dzięki subwencji Ministerstwa Administracji i Cyfryzacji drugi numer „Almanachu Karaimskiego", zawierający edycję listów Ananiasza Zajączkowskiego 
do Hadży Seraji Chana Szapszała i Aleksandra Mardkowicza. Listy do Seraji Szapszała przedstawił po raz pierwszy w 1991 r. w Wilnie ówczesny kustosz Biblioteki Wróblewskich Litewskiej Akademii Nauk, Romualdas Firkovičius na konferencji poświęconej 30 rocznicy śmierci Hachana Szapszała. Szerzej omówił ten temat na konferencji poświęconej 90 rocznicy urodzin prof. Ananiasza Zajączkowskiego w referacie „Prof. Ananiaszo Zajączkowskio laiskai prof. Serajai Chan Šapšalui”"28. I to właśnie R. Firkovičius, historyk - archiwista, świetny badacz dokumentów dotyczących życia Karaimów w Wielkim Księstwie Litewskim, zasugerował mi konieczność wydania tych listów ze względu na ich wartość poznawczą. Nadal prowadzę kwerendę archiwalną, a także opracowuję listy Ojca z podróży naukowych pisane w latach 1950-1970 do Żony i Rodziny.

„Ananiasz Zajączkowski postawił sobie pomnik dzięki setkom cenionych w nauce światowej prac badawczych, licznym dziesiątkom uczniów różnych pokoleń, wieloletniej owocnej działalności organizacyjnej oraz rozszerzeniu kontaktów i bliższej współpracy z wieloma zagranicznymi ośrodkami naukowymi. Zapewnia Mu to na zawsze miejsce wśród najbardziej zasłużonych przedstawicieli naszej rodzimej orientalistyki" ${ }^{29}$.

28 R. Firkovičius, Prof. Ananiaszo Zajaczkowskio laiškai prof. Serajai Chan Šapšalui, [w:]. Kipčiaku Tiurku Orientas Lietuvoje, s. 63-70.

29 S. Kałużyński, Działalność organizacyjna prof. A. Zajączkowskiego, „Przegląd Orientalistyczny”, 1971, nr 3 (79), s. 279. 


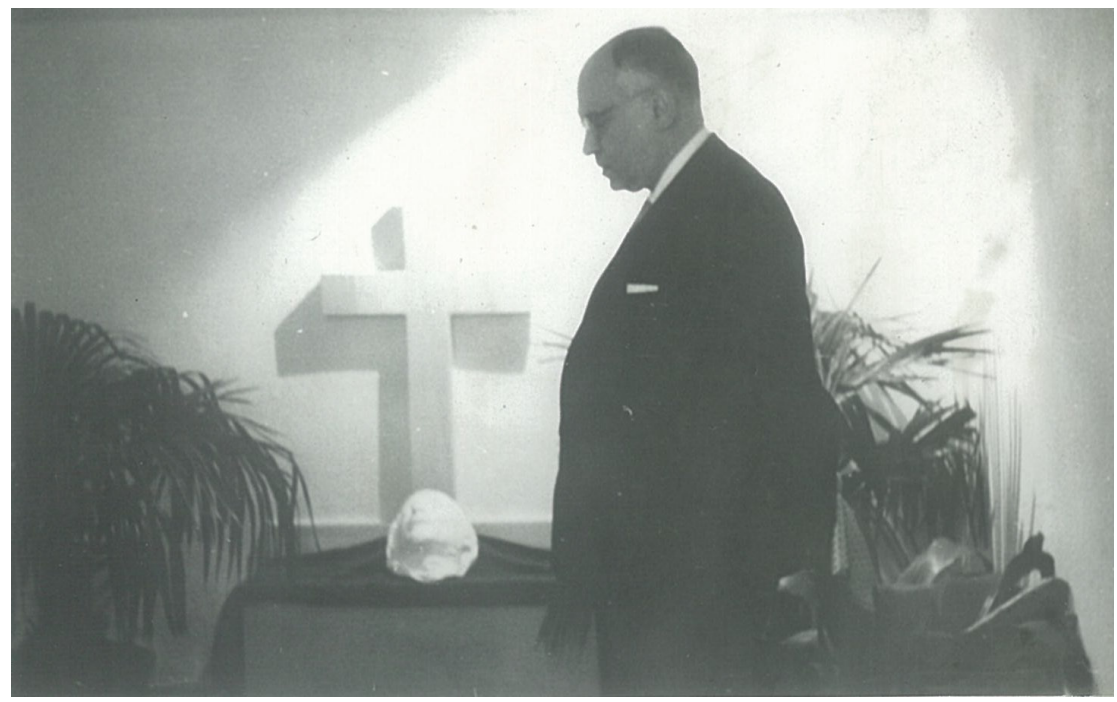

Ryc. I. Ananiasz Zajączkowski w Muzeum Adama Mickiewicza w Stambule (grudzień 1955).

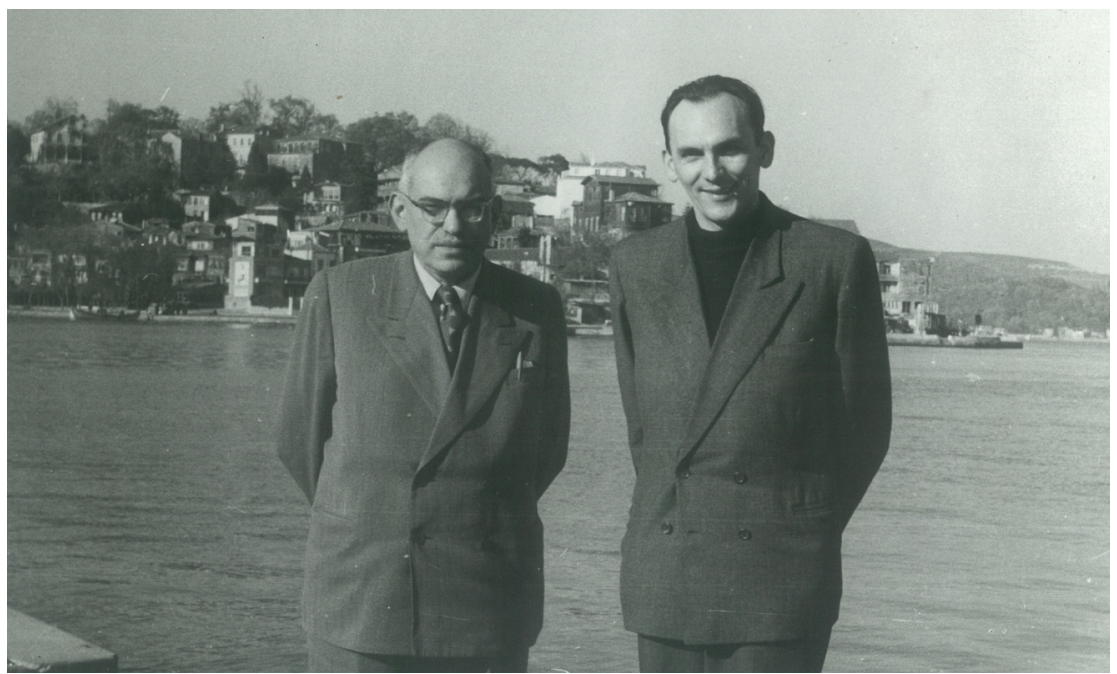

Ryc. 2. Ananiasz Zajączkowski i Zdzisław Żygulski jun. w Stambule (grudzień 1955). 


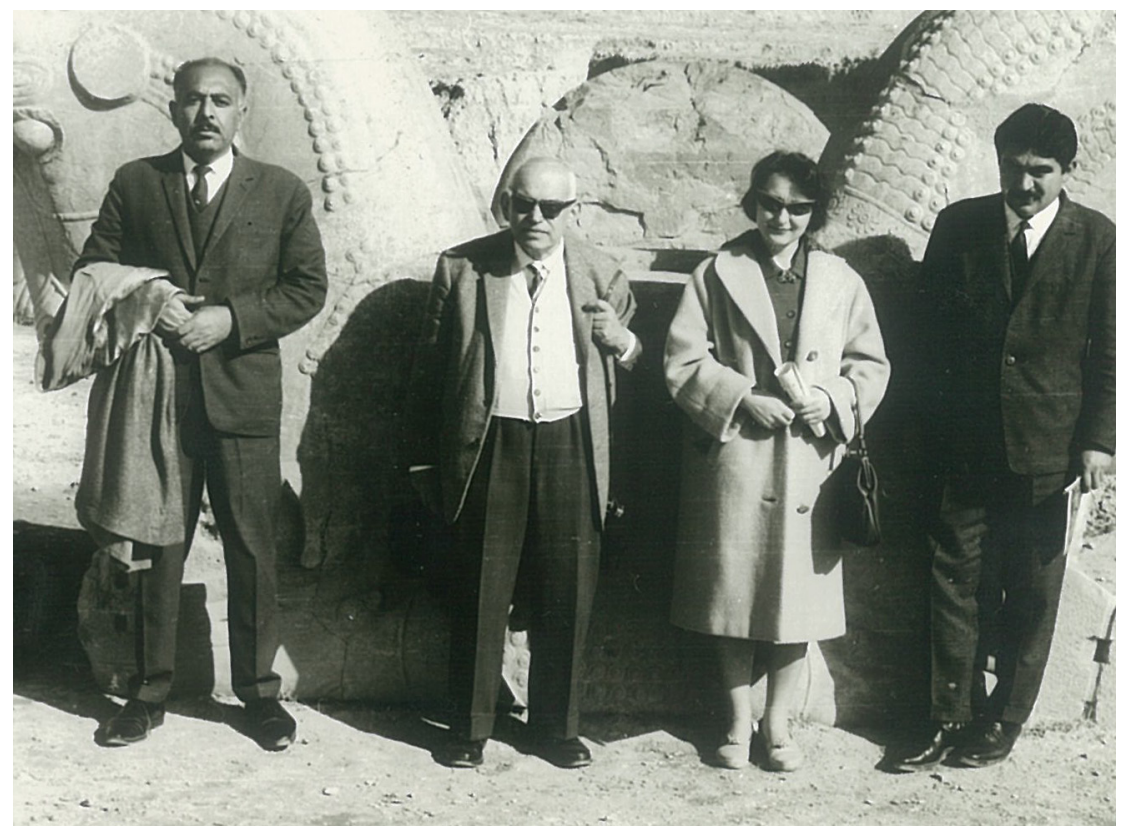

Ryc. 3. Ananiasz Zajączkowski i Barbara Majewska w Persepolis (1966). 